\title{
Gambaran Fungsi Ginjal pada Pasien Gagal Jantung dengan Fraksi Ejeksi Menurun dan Fraksi Ejeksi Normal di RSUP Dr. M. Djamil Padang
}

\author{
Annisa Rahmi Adriyanti ${ }^{1}$, Eka Fithra Elfi ${ }^{2}$, Hardisman $^{3}$
}

\section{Abstrak}

Gagal jantung dapat dikelompokkan menjadi HF-REF (Heart Failure with Reduced Ejection Fraction) dan HFPEF (Heart Failure with Preserved Ejection Fraction). Gagal jantung dapat menyebabkan kerusakan jaringan intersisial ginjal akibat tidak memadainya perfusi ke ginjal, yang akan berdampak pada penurunan fungsi ginjal. Tujuan penelitian ini adalah mengetahui gambaran fungsi ginjal pada pasien gagal jantung dengan EF (Ejection Fraction) menurun dan EF Normal di RSUP Dr. M. Djamil Padang. Penelitian ini bersifat deskriptif dengan desain potong lintang dengan sampel penelitian adalah rekam medic seluruh pasien gagal jantung yang dirawat di bagian jantung RSUP Dr. M. Djamil Padang pada tahun 2014. Jumlah sampel yang memenuhi kriteria penelitian adalah sebanyak 102 pasien. Hasil studi menunjukkan rerata LFG (Laju Filtrasi Glomerulus) pada pasien HF-PEF $(50.88 \pm 20.90 \mathrm{ml} / \mathrm{mnt} / 1,73 \mathrm{~m} 2)$ lebih rendah dari pada pasien $\operatorname{HF}-\operatorname{REF}\left(63.27 \pm 27.45 \mathrm{ml} / \mathrm{mnt} / 1,73 \mathrm{~m}^{2}\right)$. Pada HF-PEF hanya 3,2\% pasien yang fungsi ginjalnya normal, dan terdapat $6,5 \%$ pasien yang mengalami gagal ginjal, sedangkan yang lainnya mengalami penurunan fungsi ginjal dalam berbagai derajat. Pada HF-REF, tidak terdapat pasien yang mengalami gagal ginjal dan terdapat $15,5 \%$ pasien yang fungsi ginjalnya normal, sedangkan yang lainnya mengalami penurunan fungsi ginjal dalam berbagai derajat.Fungsi ginjal pasien HF-PEF lebih buruk daripada pasien HF-REF.

Kata kunci: gagal jantung, ejection fraction, fungsi ginjal

\begin{abstract}
Heart failure can be divided into Heart Failure with Reduced Ejection Fraction (HF-REF) and Heart Failure with Preserved Ejection Fraction (HF-PEF). Heart failure has a various complications to damage interstitial tissue of the glomeruli, which is caused by inadequate perfusion of the kidneys due to heart failure, will cause result in decreased kidney function. The objective of the study was to describe the kidney function in HF-REF and HF-PEF at RSUP Dr. M. Djamil Padang. A cross sectional study was conducted descriptively with the sample all of hospitalized heart failure patients of Cardiology Department at RSUP Dr. M. Djamil Padang in 2014. Total of medical records that fulfilled

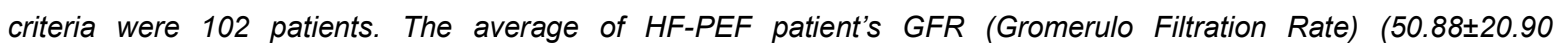
$\left.\mathrm{ml} / \mathrm{mnt} / 1,73 \mathrm{~m}^{2}\right)$ was lower than HF-REF patient's $\left(63.27 \pm 27.45 \mathrm{ml} / \mathrm{mnt} / 1,73 \mathrm{~m}^{2}\right)$. There were about $3.2 \%$ of HF-PEF patients who had normal kidney function, about $6.5 \%$ who had kidney failure, and the others had worsening kidney failure in various grade. None of HF-REF patients had heart failure, about 15,5\% patients had normal kidney function, and the other had worsening kidney failure in various grade. The kidney function of HF-PEF patients was worse than HF-REF patients.
\end{abstract}

Keywords: heart failure, ejection fraction, kidney function

Affiliasi penulis: 1. Prodi Profesi Dokter FK Unand (Fakultas Kedokteran Universitas Andalas Padang), 2. Bagian Jantung dan Pembuluh Darah FK Unand/RS Dr. M. Djamil Padang, 3.Bagian IImu kesehatan Masyarakat FK Unand
Korespondensi : Annisa Rahmi Adriyanti, Email:

nsa.orient@gmail.com Telp: 081266338680 


\section{PENDAHULUAN}

Penyakit kardiovaskular adalah penyebab kematian nomor satu di dunia. Pada tahun 2012, sekitar 17,5 juta orang meninggal karena penyakit kardiovaskular. ${ }^{1}$ Gagal jantung merupakan tahap akhir dari seluruh penyakit jantung. Gagal jantung akan meningkatkan morbiditas dan mortalitas pada penderita penyakit jantung. ${ }^{2}$ Gagal jantung merupakan suatu sindrom dimana pasien memiliki gejala dan tanda yang khas karena kelainan fungsi atau struktur jantung. $^{3}$

Prevalensi gagal jantung terus mengalami peningkatan. Tahun 2008, diperkirakan terdapat 5,7 juta orang Amerika berusia $>20$ tahun (2,4\%) menderita gagal jantung. Pada tahun 2010, terdapat sekitar 6,6 juta orang Amerika berusia > 18 tahun $(2,8 \%)$ yang mengalami gagal jantung. Tahun 2030 diperkirakan akan terjadi penambahan penderita gagal jantung sekitar 3 juta orang (25\%). ${ }^{4}$

Dalam Profil Kesehatan Indonesia tahun 2008, gagal jantung menyebabkan 13.395 orang menjalani rawat inap, dan 16.431 orang menjalani rawat jalan di seluruh rumah sakit di Indonesia dan presentase Case Fatality Rate sebesar $13,42 \% .^{5}$

Salah satu pemeriksaan non-invasif yang dilakukan untuk gagal jantung adalah ekokardiografi. Melalui pemeriksaan ekokardiografi dapat diketahui fungsi ventrikel kiri dengan melihat fraksi ejeksi (Ejection Fraction, EF) ventrikel kiri dan mengukur volume dan waktu pengisian ventrikel. ${ }^{6}$ Berdasarkan $E F$, gagal jantung dapat dibedakan menjadi Gagal jantung dengan EF menurun (Heart Failure-Reduced Ejection Fraction, HF-REF) dan gagal jantung dengan EF Normal (Heart Failure-Preserved Ejection Fraction, HF-PEF). ${ }^{7}$

HF-REF adalah gagal jantung yang terjadinya karena gangguan kontraksi otot ventrikel kiri yang diikuti dengan menurunnya kekuatan pompa jantung. HF-PEF adalah gagal jantung yang terjadi akibat menurunnya daya relaksasi otot dan gangguan pengisiann ventrikel kiri yang akan menyebabkan menurunnya volume pengisian. Pada kondisi ini didapatkan fraksi ejeksi yang $>50 \%{ }^{8}$

Gagal jantung memiliki berbagai komplikasi terhadap sistem organ lainnya, salah satunya ginjal.
Penurunun fungsi jantung menyebabkan penurunan dari curah jantung. Tidak memadainya perfusi ke ginjal menyebabkan kerusakan pada jaringan intersisial dari glomerulus yang akan menyebabkan penurunan fungsi ginjal. Penurunan aliran darah ke pembuluh darah aferen ginjal akan dikompensasi oleh tubuh dengan aktifasi sistem simpatis, Renin-AngiotensinAldosteron System dan beberapa polipeptida. Hal ini akan menyebabkan laju filtrasi ginjal akan berkurang dan dapat menyebabkan penurunan fungsi ekresi dari ginjal yang berakibat menumpuknya zat sisa dalam tubuh. $^{9}$

Disfungsi ginjal merupakan faktor resiko independen untuk kesakitan dan kematian pada gagal jantung baik pada yang simtomatik ataupun yang asimtomatik. Patofisiologi penurunan fungsi ginjal pada gagal jantung diduga akibat adanya reduced atau penurunan EF dan penurunan cardiac output. ${ }^{9}$

Penurunan fungsi ginjal terjadi pada $21 \%$ pasien gagal jantung. ${ }^{10}$ Peneliti lain melaporkan terjadinya perburukan fungsi ginjal pada $27 \%$ pasien yang dirawat karena gagal jantung. ${ }^{11}$ Suatu penelitian meta-analisis dan review kepustakaan dilaporkan bahwa $63 \%$ dari 80.098 pasien gagal jantung mengalami perburukan fungsi ginjal. Tingkat perburukan fungsi ginjal sebanding dengan peningkatan angka kematian. Setiap kenaikan kadar kreatinin serum sebesar $0,5 \mathrm{mg} / \mathrm{dl}$ terjadi peningkatan angka kematian sebesar $15 \%{ }^{12}$

Hasil investigasi CHARM (Candesartan in Heart Failure Assessment of Reduction of Mortality and Morbidity) pada 2.680 pasien gagal jantung akut, didapatkan bahwa setiap penuruan LFG sebesar 10 $\mathrm{ml} /$ menit maka akan meningkatkan risiko kematian atau rawatan ulang di Rumah Sakit sebesar $10 \% .{ }^{13}$

Insiden penurunan fungsi ginjal pada gagal jantung akut juga lebih besar pada pasien HF-REF dibandingkan pasien HF-PEF, yakni sebesar $70 \%$ pada pasien yang mengalami penurunan fungsi ginjal adalah pasien HF-REF. ${ }^{14}$

\section{METODE}

Jenis penelitian ini adalah observasional deskriptif dengan pendekatan cross sectional. Penelitian dilakukan di Bagian Rekam Medik RSUP 
Dr. M. Djamil Padang. Populasi penelitian adalah rekam medik pasien yang dirawat di Instalasi Pusat Jantung RSUP Dr. M. Djamil pada periode 1 Januari 2014 sampai 31 Desember 2014. Sampel penelitian adalah bagian populasi yang memenuhi kriteria inklusi dan tidak memenuhi kriteria ekslusi. Kriteria inklusi yakni pasien gagal jantung yang memiliki kelengkapan data. Kriteria ekslusi adalah pasien yang pernah dilakukan angiografi koroner, pasien dengan diagnosis sekunder penyakit ginjal kronik, DM dengan nefropati.

\section{HASIL}

Pada Periode 1 Januari 2014 sampai 31 Desember 2014, jumlah pasien yang memenuhi kriteria inklusi dan tidak memiliki kriteria ekslusi untuk dijadikan sampel penelitian adalah 102 pasien.

Pada Tabel 1, pasien gagal jantung di RSUP Dr. M. Djamil Padang yang berjenis kelamin laki-laki lebih banyak dari pada perempuan yakni sebanyak 64 orang atau sebesar $62,7 \%$. Sebanyak $69,6 \%$ (71 orang) pasien gagal jantung merupakan pasien HFREF. Pada kelompok HF-REF, 73,2\% (52 orang) berjenis kelamin laki-laki. Pada kelompok HF-PEF jumlah pasien wanita jauh lebih banyak yakni $61,3 \%$ (19 orang).

Tabel 1. Karakteristik pasien gagal jantung berdasarkan EF dan jenis kelamin

\begin{tabular}{lccc}
\hline \multirow{2}{*}{ Karakteristik } & \multicolumn{3}{c}{$\mathbf{f ( \% )}$} \\
\cline { 2 - 4 } & Laki-laki & Perempuan & Total \\
\hline HF-REF & $52(73,2)$ & $19(26.8)$ & $71(69,6)$ \\
HF-PEF & $12(38,7)$ & $19(61,3)$ & $31(30,4)$ \\
Total & $64(62,7)$ & $38(37,3)$ & $102(100)$ \\
\hline
\end{tabular}

Pada Tabel 2 tampak, rerata $\pm S D$ usia pasien HF-PEF lebih tinggi dibanding pasien HF-REF yakni $58,16 \pm 14,26$ tahun. Rerata berat badan pasien HFREF mempunyai nilai yang lebih tinggi dari pada pasien HF-PEF, yakni $62,55 \pm 10,22 \mathrm{~kg}$.

Nilai kreatinin serum, rerata kreatinin serum kelompok HF-PEF lebih tinggi daripada kelompok HFREF yakni $1,53 \pm 1,55 \mathrm{mg} / \mathrm{dl}$. Sama halnya dengan kreatinin serum, nilai ureum pasien HF-PEF juga lebih tinggi yakni $44.19 \pm 34.98 \mathrm{mg} / \mathrm{dl}$. Rerata LFG terbaik dimiliki oleh kelompok HF-REF yakni $63,27 \pm 27,45$ $\mathrm{ml} / \mathrm{mnt} / 1,73 \mathrm{~m}^{2}$ seperti Tabel 2.
Tabel 2. Karakteristik pasien gagal jantung

\begin{tabular}{lcc}
\hline \multirow{2}{*}{ Karakteristik } & \multicolumn{2}{c}{ Rerata \pm SD } \\
\cline { 2 - 3 } & HF-REF & HF-PEF \\
\hline Usia (Tahun) & $53.45 \pm 12.01$ & $58.16 \pm 14.26$ \\
Berat Badan (Kg) & $62.55 \pm 10.22$ & $56.10 \pm 9.81$ \\
Hasil Pemeriksaan & & \\
Penunjang & & \\
Kreatinin Serum (mg/dl) & $1.29 \pm 0.49$ & $1.53 \pm 1.55$ \\
Ureum (mg/dl) & $41.18 \pm 27.40$ & $44.19 \pm 34.98$ \\
LFG (ml/mnt/1,73m²) & $63.27 \pm 27.45$ & $50.88 \pm 20.90$ \\
EF (\%) & $32.10 \pm 9.53$ & $64.58 \pm 8.82$ \\
\hline
\end{tabular}

Etiologi gagal jantung pasien yang menjadi subjek pada penelitian ini dapat dilihat pada Tabel 3. Pada pasien HF-PEF etiologi terbanyak yang menyebabkan gagal jantung tipe ini adalah HHD (45.2\%). Penyebab terbanyak kedua adalah CAD (25.8\%). Berbeda dengan pasien HF-REF, 54.9\% penyebab terjadinya gagal jantung adalah CAD. Penyebab lain yang juga memegang peranan untuk gagal jantung tipe ini adalah HHD yakni sebesar $16,9 \%$.

Pada pasien HF-PEF, diagnosis sekunder yang terbanyak adalah hipertensi yakni (35.5\%). Sedangkan pada pasien HF-REF, diagnosis sekunder terbanyak adalah pneumonia (36.6\%), disusul oleh DM (18.3\%). Seperti terlihat pada Tabel 3.

Tabel 3. Karakteristik dasar pasien berdasarkan etiologi dan diagnosis sekunder

\begin{tabular}{lcc}
\hline \multirow{2}{*}{ Karekteristik } & \multicolumn{2}{c}{$\mathbf{f ( \% )}$} \\
\cline { 2 - 3 } & $\begin{array}{c}\text { HF-REF } \\
(\mathbf{n}=\mathbf{7 1})\end{array}$ & $\begin{array}{c}\text { HF-PEF } \\
(\mathbf{n}=\mathbf{3 1})\end{array}$ \\
\hline Etiologi & & \\
CAD & $39(54.9 \%)$ & $8(25.8 \%)$ \\
HHD & $12(16.9 \%)$ & $14(45.2 \%)$ \\
VHD & $9(12.7 \%)$ & $4(12.9 \%)$ \\
Diagnosis Sekunder & & \\
Pneumonia & $26(36.6 \%)$ & $8(25.8 \%)$ \\
Hipertensi & $11(15.5 \%)$ & $11(35.5 \%)$ \\
DM & $13(18.3 \%)$ & $4(12.9 \%)$ \\
\hline
\end{tabular}

Mayoritas pasien gagal jantung mengalami penurunan fungsi ginjal dalam berbagai derajat. Penurunan fungsi ginjal lebih berat terjadi pada kelompok pasien HF-PEF dibandingkan pasien HFREF. seperti yang terlihat pada Tabel 4 . 
Tabel 4. Gambaran fungsi ginjal pada pasien gagal jantung.

\begin{tabular}{ccc}
\hline LFG & \multicolumn{2}{c}{$\mathrm{f}(\%)$} \\
\cline { 2 - 3 }$\left(\mathbf{m l} / \mathbf{m n t} / \mathbf{1 , 7 3 \mathbf { m } ^ { 2 } )}\right.$ & HF-REF & HF-PEF \\
\hline$\geq 90$ & $11(15.5)$ & $1(3,2)$ \\
$60-89$ & $22(31)$ & $9(29)$ \\
$45-59$ & $20(28,2)$ & $9(29)$ \\
$30-44$ & $14(19,7)$ & $7(22,6)$ \\
$15-29$ & $4(5,6)$ & $3(9,7)$ \\
$<15$ atau dialysis & $0(0)$ & $2(6,5)$ \\
\hline Total & $\mathbf{7 1 ( 6 9 , 6 )}$ & $\mathbf{3 1 ( 3 0 , 4 )}$ \\
\hline
\end{tabular}

Pasien HF-REF paling banyak mengalami penurunan fungsi ginjal ringan (LFG 60-89 $\mathrm{ml} / \mathrm{mnt} / 1.73 \mathrm{~m}^{2}$ ), yakni sebesar $31 \%$. Pada HF-PEF, penurunan fungsi ginjal ringan (LFG 60-89 $\mathrm{ml} / \mathrm{mnt} / 1.73 \mathrm{~m}^{2}$ ) terjadi pada $29 \%$ pasien, sama halnya dengan penurunan fungsi ginjal ringan sedang (LFG $45-59 \mathrm{ml} / \mathrm{mnt} / 1.73 \mathrm{~m}^{2}$ ) yang juga terjadi pada $29 \%$ pasien, seperti yang tertera pada Gambar 1.

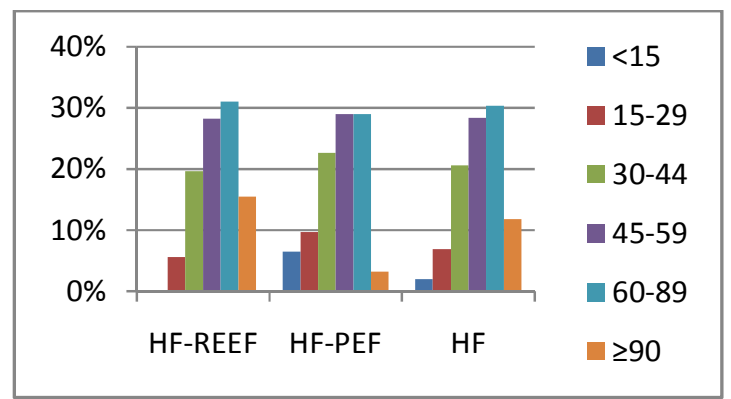

Gambar 1. Gambaran fungsi ginjal pada pasien gagal jantung

Pada Gambar 1, perburukan fungsi ginjal lebih berat terjadi pada pasien HF-PEF. Pada HF-PEF hanya $3,2 \%$ pasien yang fungsi ginjalnya normal, dan terdapat $6,5 \%$ pasien yang mengalami gagal ginjal. Pada HF-REF, tidak terdapat pasien yang mengalami gagal ginjal dan terdapat $15,5 \%$ pasien yang fungsi ginjalnya normal.

\section{PEMBAHASAN}

Jumlah pasien HF-REF lebih banyak dari pada HF-PEF. Sebesar $69,6 \%$ pasien gagal jantung merupakan pasien HF-REF dan $30,4 \%$ pasien HFPEF. Hal ini sesuai dengan guideline ESC 2012, setidaknya lebih dari $50 \%$ pasien gagal jantung merupakan kelompok HF-REF. ${ }^{7}$ Pada penelitian tahun 2004 terdapat $21 \%$ pasien HF-PEF yang artinya pasien HF-PEF lebih sedikit dari pasien HF-REF. ${ }^{11}$

Pada penelitian ini, pasien gagal jantung yang berjenis kelamin laki-laki sebanyak $62,7 \%$. Pada pasien HF-REF sebanyak $73,2 \%$ pasien berjenis kelamin laki-laki. Hal ini sejalan dengan penelitian yang menyebutkan bahwa prevalensi gagal jantung pada laki-laki lebih tinggi dibanding perempuan, yakni $4,5 \%$ untuk laki-laki. ${ }^{15}$ Jenis kelamin laki-laki juga merupakan faktor risiko independen terjadinya gagal jantung. ${ }^{16}$

Berbeda dengan gagal jantung secara keseluruhan dan HF-REF, pada pasien dengan HFPEF, pasien perempuan jauh lebih banyak yakni $61,3 \%$. Keadaan ini sesuai dengan teori yang menyebutkan bahwa HF-PEF memiliki profil epidemiologi dan etiologi yang berbeda dengan HFREF. Pada HF-PEF, pasiennya cendrung lebih sering berjenis kelamin perempuan. ${ }^{17}$

Rerata usia untuk kelompok HF-REF adalah $53,45 \pm 12,01$ tahun. Sedangkan untuk kelompok HFPEF usia rerata pasiennya adalah $58,16 \pm 14,26$ tahun, lebih tinggi dari pada kelompok HF-REF.Hal ini sesuai teori yang menyebutkan bahwa pasien HF-PEF memiliki profil epidemiologi dan etiologi yang berbeda, dimana pada kelompok HF-PEF memiliki kecendrungan untuk terjadi pada pasien dengan usia yang lebih tua. ${ }^{17}$

Pada kelompok HF-REF rerata berat badan pasien lebih tinggi dibanding kelompok HF-PEF, yakni $62,55 \pm 10,22 \mathrm{~kg}$. Rerata berat badan yang dimiliki oleh kelompok HF-PEF, yakni $56.10 \pm 9,81 \mathrm{~kg}$. Hal ini tidak sesuai dengan teori yang menyebutkan bahwa pada HF-PEF cendrung terjadi pada pasien dengan berat badan yang lebih dibandingkan pasien HF-REF. ${ }^{17}$

Gambaran hasil pemeriksaan kreatinin serum untuk pasien HF-REF yang memiliki rerata $1,29 \pm 0,49$ $\mathrm{mg} / \mathrm{dl}$. Hasil ini lebih tinggi dibandingkan nilai rujukan untuk kreatinin serum di RSUP Dr. M. Djamil Padang, yakni 0,6-1,1 mg/dl. Kelompok HF-PEF memiliki nilai rerata yang lebih tinggi yakni $1,53 \pm 1,55 \mathrm{mg} / \mathrm{dl}$. Penelitian yang dilakukan tahun 2004, menggunakan peningkatan nilai kreatinin serum sebagai kriteria perburukan fungsi ginjal, yakni peningkatan $\geq 0,3$ 
mg/dl dibandingkan dengan kadar awal. Dari peneltian tersebut dilaporkan terjadinya perburukan fungsi ginjal pada $27 \%$ pasien yang dirawat karena gagal jantung, yang akan berhubungan dengan prognosis yang buruk. $^{11}$

Etiologi terbanyak untuk pasien pasien HF-REF adalah CAD (Coronary Artery Disease) yakni sebesar $54,9 \%$. Hal ini sesuai dengan Guideline AHA 2013, bahwa penyebab utama dari HF-REF adalah $C A D^{15}$. Pada penelitian yang dilakukan Owan, et al (2006), CAD terjadi pada $63.7 \%$ pasien HF-REF. ${ }^{18}$ Penelitian tahun 2009, CAD merupakan etiologi terbanyak dari pasien gagal jantung, yakni terdapat $52 \% .{ }^{19}$ Pada pasien HF-PEF etiologi terbanyak dari pasien ini adalah HHD (45.2\%). HF-PEF paling sering terjadi pada wanita berusia tua dengan riwayat hipertensi, hipertensi dapat berujung menjadi HHD yang akan bermanifestasi sebagai gagal jantung. ${ }^{15}$

Diagnosis sekunder terbanyak pada kelompok HF-PEF adalah hipertensi (35.5\%). Hal ini sama dengan penelitian yang dilakukakan oleh Lee et al (2009) yang menemukan bahwa hipertensi terjadi pada $26 \%$ pasien gagal jantung. ${ }^{19}$ Hipertensi lebih banyak terjadi pada pasien dengan HF-PEF (35.5\%) dibanding pasien HF-REF (15.5\%). Hal ini sesuai dengan penelitian tahun 2006, yakni hipertensi terjadi pada $62.7 \%$ pasien HF-PEF dan $48 \%$ pasien HFREF. ${ }^{18}$

Dari penelitian terlihat bahwa $88,2 \%$ pasien gagal jantung mengalami penurunan fungsi ginjal, mulai dari penurunan fungsi ringan sampai dengan gagal ginjal. Persentasi penurunan fungsi ginjal pada penelitian ini lebih besar dibanding beberapa penelitian sebelumnya. Smith et al tahun 2006 melaporkan terjadinya perburukan fungsi ginjal pada $63 \%$ dari 80.098 orang pasien yang dirawat dengan gagal jantung. ${ }^{12}$ Chittineni et al (2007), melaporkan angka kejadian yang lebih kecil yaitu $21 \%{ }^{10}$ Perbedaan yang signifikan ini mungkin dikarenakan perbedaan indikator yang dipakai sebagai kriteria perburukan fungsi ginjal.

Gambaran fungsi ginjal pada pasien HF-PEF menunjukkan hanya $3,2 \%$ pasien yang fungsi ginjalnya normal, yakni $\geq 90 \mathrm{ml} / \mathrm{mnt} / 1,73 \mathrm{~m}^{2}$ sedangkan sisanya mengalami penurunan fungsi ginjal pada berbagai stadium. Fungsi ginjal mayoritas yang dimiliki oleh pasien HF-PEF adalah $60-89 \mathrm{ml} / \mathrm{mnt} / 1,73 \mathrm{~m}^{2}$ dan 45-59 $\mathrm{ml} / \mathrm{mnt} / 1,73 \mathrm{~m}^{2}$ yakni masing-masing sebesar $29 \%$. Pada pasien ini juga terdapat $6,5 \%$ pasien yang mengalami gagal ginjal. Rerata LFG pada kelompok ini adalah 50,88 $\pm 20,90 \mathrm{ml} / \mathrm{mnt} / 1,73 \mathrm{~m}^{2}$ lebih rendah daripada gagal jantung secara keseluruhan dan HFREF.

Pada pasien HF-REF, fungsi ginjal pada kelompok ini lebih baik daripada kelompok HF-PEF. Tidak ditemukan pasien yang memiliki LFG $<15 \%$, artinya tidak terdapat pasien yang mengalami gagal ginjal. Fungsi ginjal normal diiliki oleh $15,5 \%$ pasien, $31 \%$ mengalami penurunan fungsi ginjal ringan. Sisanya $53,5 \%$ mengalami penurunan fungsi ginjal ringan-sedang, sedang-berat dan berat.

Berbeda dengan hasil penelitian ini, Ronco et al (2008) menyebutkan bahwa perburukan fungsi ginjal yang lebih berat terjadi pada pasien HF-REF yakni $70 \%$ dari pasien gagal jantung yang mengalami perburukan fungsi ginjal adalah pasien HF-REF. ${ }^{14}$ Pada penelitian Forman et al (2004), pasien HF-PEF $(27,35 \%)$ dan pasien HF-REF $(27,95 \%)$ mengalami penurunan fungsi ginjal dengan persentasi yang tidak terlalu berbeda. terjadi pada pasien HF-REF. ${ }^{11}$

Hasil penelitian ini berbeda dengan beberapa penelitian yang sudah ada. Pada penelitian ini didapatkan bahwa fungsi ginjal pasien HF-PEF lebih rendah dibandingkan dengan pasien HF-REF, baik dari hasil rata-rata LFG maupun stadium fungsi ginjal yang dikelompokan berdasarkan LFG. Hal ini mungkin saja terjadi karena pada penelitian ini kriteria ekslusi tidak begitu ketat. Pasien dengan riwayat DM dan hipertensi tetap dimasukkan kedalam penelitian ini.

Hipertensi merupakan faktor risiko independen untuk penyakit kardiovaskular, termasuk gagal jantung, yang akan meninggkatkan mortalitas dan morbiditas penyakit tersebut. Hipertensi akan menyebabkan kerusakan organ target, seperti penurunan fungsi ginjal. ${ }^{20}$ Pada kelompok HF-PEF, fungsi ginjal yang lebih buruk mungkin dikarenakan etiologi terbanyak adalah HHD dan penyakit komorbid terbanyak adalah hipertensi. 


\section{SIMPULAN}

Terdapat penurunan fungsi ginjal pada sebagian besar pasien gagal jantung. Fungsi ginjal pasien HF-PEF lebih buruk daripada pasien HF-REF.

\section{UCAPAN TERIMA KASIH}

Terima kasih diucapkan kepada semua pihak yang membantu penelitian ini. Terima kasih kepada Staf RSUP Dr. M. Djamil Padang, khususnya Bagian Rekam Medik atas bantuan dalam penelitian ini.

\section{DAFTAR PUSTAKA}

1. World Health Organization (WHO). Cardiovascular disease. 2015 (diunduh 16 Februari 2015). Tersedia dari: URL: HYPERLINK http://www.who. int/mediacentre/factsheets/fs317/en/

2. Maggioni AP. Review of the new esc guidelines for the pharmacological management of chronic heart failure. European Heart Journal. 2005; Supplements 7 (Supplement J): J15-J20.

3. European Society of Cardiology (ESC). ESC guidelines for the diagnosis and treatment of acute and chronic hearth failure 2012. Eur Heart. 2012; J 33:1787-1847.

4. American Heart Association (AHA). Heart disease and stroke statistics-2012 update. 2012:e2-e220.

5. Departemen Kesehatan Republik Indonesia. Profil kesehatan indonesia 2008. Jakarta: Depkes RI; 2009.hlm.62.

6. Hunt SA, Abraham WT, Chin MH, Feldman AM, Francis GS, Ganiats TG, et al. Focused update incorporated into the ACC/AHA 2005 guidelines for the diagnosis and management of heart failure in adults: A report of the American College of Cardioligy Foundation/ American Heart Association task force on practise guidelines developed in collaboration with the International Society for Heart and Lung Transplantation. J. Am. Coll. Card. 2009; 53: el-e90.

7. European Society of Cardiology (ESC). Esc guidelines for the diagnosis and treatment of acute and chronic hearth failure 2012. Eur Heart J. 2012; 33:1787-1847.

8. Panggabean MM. Gagal jantung. Dalam: Sudoyo AW, Setiyohadi B, Alwi I, Simadibrata M, Setiati S, editor (penyunting). Buku ajar ilmu penyakit dalam.
Edisi ke-6. Jakarta: Pusat Penerbitan IImu Penyakit Dalam. 2012.hlm.1133-5.

9. Ronco C, Cicoira M, McCullough PA. Cardiorenal syndrome type 1: Pathophysiological crosstalk leading to combined heart and kidney dysfunction in the setting of acutely decompensated heart failure. J Am Coll Cardiol. 2012;60(12): 1031-42.

10. Chittineni H, Miyawaki N, Gulipelli S, Fishbane S. Risk for acute renal failure in patients hospitalized for decompensated congestive heart failure. Am J Nephrology. 2007;27:55-62.

11. Forman DE, Butler J, Wang $\mathrm{Y}$, Abraham WT, O'Connor CM, Gottlieb SS, et al. Incidence, predictors at admission, and impact of worsening renal function among patients hospitalized with heart failure. J. Am. Coll. Cardiol. 2004;43:61-7.

12. Smith GL, Lichtman JH, Bracken MB, Shlipak MG, Phillips CO, DiCapua $\mathrm{P}$, et al. Renal impairment and outcomes in heart failure: Systematic review and meta-analysis. Journal of the American College of Cardiology. 2006;47(10):1987-96.

13. Hillege HL, Nitsch D, Pfeffer MA, Swedberg K, McMurray JJV, Yusuf $S$, et al. Candesartan in heart failure: Renal function as a predictor of outcome in a broad spectrum of patients with heart failure. CHARM investigators Circ. 2006;13:671-8.

14. Ronco C, Haapio M, House AA, Anavekar N, Bellomo R. Cardiorenal syndrome. J Am Coll Cardiol. 2008;52(19):1527-39.

15. American Heart Association (AHA). 2013 ACCF/AHA guideline for the management of heart failure: A report of the American College of Cardiology Foundation/American Heart Association task force on practice guidelines. J Am Coll Cardio. 2013;62(16): e240-e327.

16. Aronow WS. Epidemiology, pathophysiology, prognosis, and treatment of systolic and diastolic heart failure. Cardiology in review. 2006;14(3): 108-24.

17. Hogg K, Swedberg K, McMurray J. Heart failure with preserved left ventricular systolic function; epidemiology, clinical characteristics, and prognosis. J Am Coll Cardiol. 2004; 43: 317-327.

18. Owan TE, Hodge DO, Herges RM, Jacobsen SJ, Roger VL, Redfield MM. Trends in prevalence and outcome of heart failure with preserved ejection 
fraction. New England Journal of Medicine. 2006; 355:251-9.

19. Lee DS, Gona P, Vasan RS, Larson MG, Benjamin EJ, Wang TJ, Tu JV, et al. Relation of disease pathogenesis and risk factors to heart failure with preserved or reduced ejection fraction insights from the Framingham Heart Study of the National Heart,
Lung, and Blood Institute. Circulation. 2009; 119(24):3070-7.

20. Yogiantoro M. Pendekatan klinis hipertensi. Dalam: Sudoyo AW, Setiyohadi B, Alwi I, Simadibrata M, Setiati S, editor (penyunting). Buku ajar ilmu penyakit dalam. Edisi ke-6. Jakarta: Pusat Penerbitan Ilmu Penyakit Dalam. 2014.hlm.2259 83. 